\title{
Reflexive Traditionalism and Emergent Cosmopolitanism: Some Reflections on the Religious Imagination
}

\author{
By Bryan S. Turner
}

The theory of globalization has come to replace all other topics - structuralism, post-structuralism, postmodernism, gender, inequality and so forth - as the all-embracing paradigm of modern sociology, and in the process the debate has generated a battery of new concepts around mobilities, glocalization, globalophilia, mondialization and of course 'the second modernization' (Beck 2002). Perhaps in no other area in the social sciences has sociology been so prominent in the field of research and yet much work has to be done on both conceptual clarification and empirical inquiry. The topic has already produced a number of major publications offering an overview of the internal diversity of the field (Ritzer 2010; Turner 2010). However, the key issue within the globalization literature is quite specific, namely what are the forms of culture or consciousness that offer a normative framework for these global processes? Can a global consciousness that has been orchestrated around human rights, environmentalism and cosmopolitanism counter-balance the otherwise bleak and depressing picture of what George Ritzer (2003) has called 'the globalization of nothing' - the world-wide dystopia of empty consumerism that gouges out the significance of human culture. While the intensification of global inequality may well be the inevitable outcome of the current financial crisis (Martell 2010), many sociologists and social philosophers have identified cosmopolitan ethics as a promising response to the global movement, or more accurately displacement, of people around the world (Appiah 2006). What comes after globalization may either be the emergence of a feral society to be characterized by urban decay, water wars, over-population and pandemics, or the construction of new social bonds around a shared cosmopolitan ethic. In short, the sociology of globalization has produced an important discussion of post-national sociology around an emerging 'cosmopolitan imagination' (Delanty 2009).

Many of the key issues in the field of globalization and cosmopolitan sociology have been explored by Ulrich Beck, whose recent sociological work attempts to provide a systematic theory of these diverse developments (Beck / Sznaider 2006). There is no need here to comment in any depth on the sociology of cosmopolitanism that Beck has developed in the years following the publication of his seminal work on risk society (Beck [1986]1992; 1999). His theory is adequately described in this edition of Soziale Welt with Edgar Grande ('Jenseits des methodologischen Nationalismus'). Suffice it to say that, building on the theory of risk society, he has proposed a new periodization of modernity in which the second modernity refers to a world that has moved beyond a system of nation states with the penetration of society by diverse globalizing processes. As a result he has raised some profound issues about the epistemological assumptions of conventional national sociologies (Beck 2000). Beck has also given some prominence to the question of human rights as the quintessential expression of law in such a postnational environment. Finally, and perhaps most importantly, he has explored the idea of a new type of world consciousness in the notion of 'banal cosmopolitanism'.

The collection of articles in this special issue of Soziale Welt is a clear and vigorous testimony to the importance of these ideas and to the originality of Beck's current sociological project. These articles can also be seen as a response to some of the criticisms raised against globalization theory in general. One obvious criticism of most versions of globalization is that they fail conspicuously to examine the development of Asian societies or indeed whether Asian globalization is separate from or prior to western developments (Turner / Khondker 2010). The various articles in this collection such as the contributions to the family and 'the individualization of relationships in Japan' and David Tyfield and John Urry's article on 'Cosmopolitan

Soziale Welt 61 (2010), S. $313-318$ 
China' provide a welcome addition to the current debate around the limitations of an exclusively western view of globalization.

While recognizing Beck's attempts to develop a systematic general theory of globalization, I shall raise some general criticisms of his theory, all of which revolve around the issue of religion in modernity. I raise some empirical problems for Beck's historical characterization of modernity and thereby bring into focus some difficulties with his theory. There is no need here to dwell on the fact that religion in the classical sociology of Weber, Durkheim and Simmel was crucial to the sociological understanding of the origins and character of the modern. Before dealing with these empirical issues, we need to consider Beck's position of 'methodological nationalism'.

One problem with the early position of both Beck and Anthony Giddens is that they want to argue that, since both Weber and Durkheim based their sociology on the notion of bounded nation-states, we need to break out of these limiting assumptions in order to create a postnational sociology. I have elsewhere questioned whether the generic notion of the 'social' in Weber, Durkheim and Simmel was ever unambiguously 'national' (Turner 2006 a). It is certainly difficult to assume that in his sociology of capital accumulation Marx made any assumptions about the national character of capital.

This issue of the national and the social also emerges in a problematic way with respect to human rights. I have in my own work argued that we need to develop a normative sociological notion of 'cosmopolitan virtue' in order to come to terms with modern globalization in Vulnerability and Human Rights (Turner 2006 b), but I have severe reservations about the feasibility in the real world of what we might call post-national sovereign jurisdictions. We have to take account of the paradox that in a global world human rights are typically enforced by nation states in the absence of world government. With the current development of global securitization, we should not exaggerate the demise of the nation state and hence the implementation of human rights is severely limited. In analytical terms, the construction of a sociology of human rights remains underdeveloped (Morgan / Turner 2009).

These opening comments bring me to the core of my objections, which hinge on the problematic nature of religion to modernity. It has been often observed that, given the emphasis on economic globalization, the role of religion in the history of globalization has been neglected and that religious globalization predated contemporary secular forms of globalization by many centuries (Beckford / Demerath 2007). Early contributions to the globalization debate were explored some decades ago by sociologists of religion such as Roland Robertson. The relationship between religion, the concept of humanity and the origins of human-rights consciousness had been explored in the $1980 \mathrm{~s}$ (Robertson / Chirico 1985). Some aspects of the sociology of globalization arose out of Robertson's interest in 'intra-civilizational analysis' (Robertson 1982). The influential volume on Globalization (Robertson 1992) was a collection of essays that reflected a decade of work on religion and globalization. These foundations were followed by contributions from Peter Beyer (1994) Religion and Globalization and more recently by Mark Juergensmeyer's edited collection on Global Religions (2003) and by David Martin (2002) on Pentecostalism.

There are several issues here. Perhaps the least important is the fact that globalization appears to have been explored originally by reference to religion, but the sociology of religion is often neglected in contemporary sociological contributions to globalization theory from David Harvey and Anthony Giddens. Secondly, there is considerable neglect of the historical aspects of the globalization of religion and its interconnections with pre-modern world trade. One obvious example can be taken from the history of the Silk Routes that lasted for some 3000 years. These intercontinental trade routes connected Ancient China and the Mediterranean. Designated as 
the Silk Road (Seidenstrasse) by the German geographer Ferdinand von Richthofen in 1877, these routes played a major role in the early transmission of Buddhism to China in the first century CE. These routes also contributed to the growing dominance of Islam in Central Asia in the seventh century. In the sociology of globalization, these examples from the ancient world are almost never seriously considered. By contrast, in religious studies and the historical research on world religions, these global formations have been the topic of major investigations. In particular we can refer to the work of Marshall G.S. Hodgson (1993) who developed a postnational epistemology and theory of the world in Rethinking World History and developed the idea of a world oikoumene in his three volume The Venture of Islam exploring 'Islamicate history' from the perspective of an integrated Mediterranean system (Hodgson 1974). In these examples, the theory of world history had already gone well beyond the tradition of national methodologies of history. These empirical examples from the sociology of religion begin to raise difficulties for Beck's account of the second modernization.

Of course, the growth of these global networks for the pre-modern transmission and exchange of both material goods and cultures does not raise any necessary or fatal difficulty for Beck's argument about a second modernization. We need to demonstrate, in addition to these trade and cultural networks, the emergence of a cosmopolitan consciousness in the pre-modern period. While one can produce ample evidence about inter-connectedness through trade, cultural exchange and religious conversion, we need also to demonstrate the emergence of an openness to the outside world. Robert Holton (2009: 101) is surely correct to insist that 'to qualify as cosmopolitan, such inter-personal milieux need to exhibit some sense of inter-cultural openness'. Travel and trade do not automatically produce cosmopolitanism.

My argument is that any evangelical religion with a universalistic set of assumptions must confront the problem of the Other and out of that dialogue with alterity an early form of cosmopolitan consciousness can emerge. My first example would be the problem that confronted Saint Paul when faced by the conflicts between Jewish Christians and Gentile Christians over the relevance of the Law to the primitive Church. In claiming that there was neither Gentile nor Jew, slave nor free man, man or woman, Paul laid down a universalistic doctrine that challenged any allegiance based on blood and kinship (Badiou 2003). It is for this reason that Jacob Taubes (2004) can claim Paul as our contemporary. My argument is that Pauline 'political theology' contains a reflexive understanding of Otherness and an incipient cosmopolitan grasp of the problem of 'the world'.

Similar arguments can be presented about the early history of Islam. When Mohammed the Prophet came to construct an early polity, he was also presented with a social situation that was deeply divided between pagan, Christian and Jewish tribes. In searching for a solution to these conflicts, the Constitution of Medina is an early document that outlines a political solution to social divisions, but one that also recognized, albeit implicitly, an Other. The dialogue with other 'people of the book' has had a long history in the evolution of Islam.

There is currently ample literature on modern Islamic fundamentalism and its global reach (Mandaville 2001). Unfortunately this literature often neglects the equally important spread of less radical forms of Islam such as Sufism and the association between peaceful trade and Muslim growth (Diouf 1999). The division between a pure Islam and the hostile outside world - the world of the ignorant - is relatively modern and in particular a product of the theology of Syed Abul Ala Maududi in the 1940 s (Ahmad 2009). But fundamentalism is not the whole story. The global spread of Islam in the modern period has produced a Muslim cosmopolitanism that is in part the legacy of the traditional ummah, but which also responds to the modern development of a global diaspora (Iqtidar 2010). 
The history of religious conflict and co-operation produced a traditional consciousness about the Other and in turn one can therefore detect an early reflection on these religio-cultural differences that created an ecumenical consciousness. It may however be an exaggeration to call this 'reflexive cosmopolitanism' and it is certainly not 'reflexive modernization'. These early forms of awareness of the Other were for one thing not epistemologically open; they were based on the assumption that other traditions were either defective or false. They could be tolerated but they were nevertheless departures from an absolute revealed Truth. The interfaith tolerance that is often associated with Islamic Spain or the millet system of the Ottoman Empire was still based on an assumption about the superiority of Islam. Tolerance of difference has had a slow, fragile and uncertain development, and in my view we have to wait for Leibniz to give a plausible philosophical justification for taking other beliefs seriously (Turner 2005). However, I follow Holton (2009: 81) in rejecting the assumption that 'cosmopolitanization and the cosmopolitan outlook are essentially very recent phenomena'. If the empirical validity of the idea of a second modernity is in doubt, the theoretical structure of Beck's argument may be insecure.

We can in thinking about these pre-modern foundations of cosmopolitanism refer to them as examples of 'reflexive traditionalism'. In Christianity and Islam, this reflexivity emerged out of a world of cultural contact (through global trade) and as a result of global evangelical competition for world influence. Nevertheless, because both New Testament and Qur'an were and continue to be treated as revelations of a singular Truth, there were certain limitations on these early forms of world consciousness. We can claim through this brief commentary that the conditions for such a reflexive traditionalism were mobility and exchange, an evangelical religious culture that undermined the idea that a religious community ('church' or ummah) is merely an extension of kinship relations, the presence of alternative religious traditions in a competitive relationship, and a theological critique of idolatry. Reflexive traditionalism did not however generate what we might call a 'vernacular hermeneutics of doubt' in that these religions assumed an unquestioned notion of revealed Truth that had exclusionary consequences. These elementary forms of cosmopolitanism could not cope easily with the possibility of apostasy.

These historical problems create significant empirical problems for Beck's claims about a second modernization. However, the development of religion in the modern world does appear to verify one important feature of Beck's theory about modernity, namely the idea of 'individualization'. There is widespread agreement in the sociology of religion that one major trend in contemporary religious life is towards 'spirituality' which is defined as post-institutional, global, hybrid, and post-orthodox (Hunt 2005). It is partly a result of the growth of online religion, and partly a consequence of consumer youth cultures that have an experimental attitude towards religion (Hulsether 2000). These self-consciously post-orthodox hybrid trends in personal religiosity are not confined to Christianity, but are widespread in Asia where there is a powerful mixture of traditional practice and the commodification of religion (Kitiarsa 2008). Although Beck's periodization of modernity is not entirely supported by the historical evidence, the notion of religious individualization provides an important insight into changing subjectivities in the modern period.

\section{References}

Ahmad, Irfan (2009): Islamism and Democracy in India. The transformation of Jamaat-e-Islami, Princeton - Oxford.

Appiah, Kwame A. (2006): Cosmopolitanism. Ethics in a World of Strangers, New York.

Badiou, Alain (2003): Saint Paul. The Foundation of Universalism, Stanford.

Beck, Ulrich ([1986] (1992): Risk Society, London. 
Beck, Ulrich (1999): World Risk Society, Cambridge.

Beck, Ulrich (2000): The cosmopolitan perspective: sociology in the second age of modernity, in: British Journal of Sociology 51 / 1, pp.79-105.

Beck, Ulrich (2006): Cosmopolitan Vision, Cambridge.

Beck Ulrich / Nathan Sznaider (2006): Unpacking cosmopolitanism for the social sciences: a research agenda, in: British Journal of Sociology 57 / 1, pp.1-23.

Beckford, James A. / N.Jay Demerath (eds.) (2007): The Sage Handbook of Sociology of Religion, London.

Beyer, Peter (1994): Religion and Globalization, London.

Delanty, Gerard (2009): The Cosmopolitan Imagination. The Renewal of Critical Social Theory, Cambridge.

Diouf, M. (1999): The Senegalese Murid Trade Diaspora and the Making of a Vernacular Cosmopolitanism, in: Public Culture 12 / 3, pp.679-702.

Hodgson, Marshall G.S. (1974): The Venture of Islam, Chicago.

Hodgson, Marshall G.S. (1993): Rethinking World History. Essays on Europe, Islam and World History, Cambridge.

Holton, Robert J. (2009): Cosmopolitanisms. New Thinking and New Directions, Basingstoke.

Hulsether, M.D. (2000): Like a Sermon: popular religion in Madonna videos, in: Bruce D. Forbes / Jon H. Mahan (eds.) (2000), Religion and Popular Culture, Berkeley, pp.77-100.

Hunt, Stephen (2005): Religion and Everyday Life. The new sociology, London.

Iqtidar, Humeira (2010): Muslim cosmopolitanism: contemporary Practices and social theory, in: Bryan S. Turner (ed.) (2010), The Routledge International Handbook of Globalization Studies, London, pp. 622-634.

Juergensmeyer, Mark (ed.) (2003): Global Religions: An Introduction, Oxford.

Kitiarsa, Pattana (ed.) (2008): Religious Commodifications in Asia. Marketing Gods, London-New York.

Mandaville, Peter (2001): Transnational Muslim Politics. Reimagining the Umma, London - New York.

Martell, Luke (2010): The Sociology of Globalization, Cambridge.

Martin, David (2002): Pentecostalism: the world their parish, Oxford.

Morgan, Rhiannon / Bryan S. Turner (eds.) (2009): Interpreting Human Rights. Social Science Perspectives, London.

Ritzer, George (2003): The Globalization of Nothing, London.

Ritzer, George (2010): Globalization. A Basic Text, Oxford.

Robertson, Roland (1982): Societies, individuals and sociology: intra-civilizational themes, in: Theory Culture \& Society $1 / 2$, pp.6-17.

Robertson, Roland (1992): Globalization. Social Theory and Global Culture, London.

Robertson, Roland / JoAnn Chirico (1985): Humanity, globalization and worldwide religious resurgence, in: Sociological Analysis 46 / 3, pp.219-242.

Taubes, Jacob (2004): The Political Theology of Paul, Stanford.

Turner, Bryan S. (2002): Cosmopolitan Virtue, Globalization and Patriotism, in: Theory Culture \& Society 19 / 1-2, pp.45-64.

Turner, Bryan S. (2005): Leibniz, Islam and Cosmopolitan Virtue, in: Theory Culture \& Society 22 / 6, pp.139-147.

Turner, Bryan S. (2006 a): Classical sociology and cosmopolitanism: a critical defence of the social, in: British Journal of Sociology 57 / 1, pp.133-151.

Turner, Bryan S. (2006 b): Vulnerability and Human Rights, University Park / PA. 
Turner, Bryan S. (ed.) (2010): The Routledge International Handbook of Globalization Studies, London. Turner, Bryan S. / Habibul Haque Khondker (2010): Globalization East and West, London.

Prof. Bryan S. Turner

The Graduate Center City University of New York 365 Fifth Avenue New York City NY 10016-4309 USA bturner@gc.cuny.edu 